\title{
MORTGAGES-THE GENESIS OF THE LIEN THEORY
}

WIIIAM H. LIOYD

Everyone is supposed to know what a mortgage is. With most the experience is personal; in the course of a generation few roof trees avoid this affliction. Yet on closer examination it will be found that much mental confusion exists as to the nature of the transaction; which is not to be wondered at, seeing that few courts in the United States are in full accord upon the subject, and that in many of the states the instrument in common use is in flat contradiction to the accepted theory. Whether the so called title or so called lien theory prevails, there are many incongruities in the application of both doctrines, making the subject difficult to deal with as a general problem of jurisprudence, although from a practical point of -view, the discrepancies cause less harm than might possibly be anticipated, owing to the fact that a mortgage question is usually a local question, answered by empirical rules, well, apprehended, if not wholly understood by the indigenous conveyancer.

The statement sometimes found in the older books that the English law of mortgage is borrowed from the Roman law must not be taken literally. Comparative law warns us against assuming a common source for all institutions designed to meet analogous needs. According to common accounts the Roman law of real security went through three stages. ${ }^{1}$ The oldest form was the fidicia, an actual conveyance by borrower to lender, formal and effectual in law to vest ownership in the lender (mancipatio or in jure cessio), subject to an agreement (contractus fiduciae) that upon due payment of the debt the lender would reconvey the property. Upon payment of the debt and refusal to reconvey, the debtor had an action, which entailed infamy upon the creditor; and, by the lex commissoria, abolished by Constantine, upon nonpayment of the debt the property passed absolutely to the creditor. The second form was the pignus (pawn) which arose by transfer of the possession to the creditor, the ownership remaining with the borrower. The third form was the hypotheca, a pledge by agreement without change of possession, first recognized in connection with the right of the landlord over the goods of his tenant, and later extended to all cases in which it was agreed between borrower and lender that any property should be security for a debt without transfer of possession to the

\footnotetext{
${ }^{1}$ Salkowski, Roman Private Law (Whitfield transl. 1886) 480; Hunter, Roman Law (3d ed. I897) 430-434; Buckland, Text-Book of Roman Law (I921) 470. Cf. Wigmore, The Pledge-Idea III. (1898) II HARv. L. REv. I8, 3I.
} 
lender. So also by operation of law (tacita hypotheca) an implied hypothec was given to certain classes of creditors over the property of their debtors, as in the case of the exchequer; or of wives, minors, and legatees over the property of husbands, curators, and heirs. The advantage of the hypothec lay in its flexibility; its disadvantage was the ease with which it could be used to give fraudulent preferences, a fault to a great extent overcome in modern continental jurisprudence by systems of registration. The hypothec of the Roman law applied equally to land and chattels, but in many modern states it is now limited to immovable property. ${ }^{2}$

If England had followed the Roman law it is probable that it would have copied some mature form of the hypothec in contemporary use. But in Europe during the Middle Ages the hypothec was for a time almost lost sight of amidst a welter of barbarian customs and crude experiments at land-gage. ${ }^{3}$ The feudal attitude toward the alienability of land was very different from that of the Roman republic. In such conveyancing as there was it is probable that here and there a learned clerk preserved in some half understood Latin form a phrase or two of Roman origin. But, as Professor Hazeltine has shown, the English law of gage is Germanic, "starts from the conception, in the AngloSaxon days of barter and self-help, that wed or vadium delivered to the gagee is a provisional satisfaction, a provisional payment, a redeemable forfeit." 4 In the ensuing years, as the principle of collateral security slowly developed, the law went through many changes, saw many experimental forms of pledging land, a proceeding repugnant to the sentiments of a society where land is family property or has recently been so regarded. The story is, after all, only a part of the history of the growth of credit transactions, so difficult for the primitive mind to grasp; so necessary in an age of co-operation.

As is well known, the form of pledge of land which ultimately prevailed was that known as the mortgage, simple in theory; roughly corresponding in development to the stage reached by the Roman fiducia. As it still is in form so it was at first in fact, a conveyance of the legal title to the lender, subject to a provision that if the borrower paid the debt on a prescribed day, the legal title should revest in him, and he or his heirs might reënter. If the debt was not paid on the day named, the estate of the creditor became absolute. After default no right of redemption was admitted. ${ }^{5}$ The mortgagee, in short, took an estate in fee defeasible upon condition subsequent, and in the books of

\footnotetext{
${ }^{2}$ Holland, Jurisprudence (x2th ed. I9I7) 232-233. French Civil Code, art. 21I9.

${ }^{3}$ Brissaud, History of French Private Law (Cont. Leg. Hist. Series, 1912) 602 et seq.

"Hazeltine, The Gage of Land in Mediaeval England (I904) I7 HARv. L. Rev. 549, (1905) I8 HaRv. L. Rev. 36. Reprinted 3 Sel. Essays in Anglo-Aner. Leg. Hist. (1909) 646.

${ }^{5}$ Britton, bk. 3, ch. 15, sec. 6; Coke, Littleton, $*_{205}$; 2 Pollöck and Maitland, Hist. Eng. Law (2d ed. 1905) I22; 3 Holdsworth, Hist. Eng. Law (1909) 110.
} 
the time the law of mortgages is treated as part of the law of estates on condition. True, the estate of the lender was until default a security; if he died the debt was payable to his executor, as Littleton puts it, "because the money at the beginning trenched to the feofee in manner as a dutie." But the strictness with which conditions were construed at law tended to obscure this phase of the transaction. An estate, as Coke observes, was not to be divested without true and effectual payment. ${ }^{b}$ As a device of the period of strict law, the mortgage, so shaped, was in harmony with the social and economic conditions. As long as the administration of justice is slow, weak and formal, the creditor will secure himself by that possession which is said of-old to be nine points in the law. The borrower, if he would obtain the accommodation, must take the risk incidental to his unfavorable position.

The interference of the court of chancery with the mortgage contract was contemporaneous with and in fact a part of the movement for law reform through equity jurisprudence. Just as in the case of penal bonds, relief in chancery against the strict terms of mortgages was first given on special grounds. But as early as the reign of James $I$ the practice of relieving the mortgagor in default upon payment of debt and interest seems to have become common, and was well established by the time of Charles I. ${ }^{7}$ The policy was not without its critics, among them Lord Chief Justice Hale who laments that "by the growth of equity the heart of the common law is eaten out." 8 But the principles adopted in chancery prevailed because, without the aid of legislation, they gave effect to the economic tendencies of the time. The mortgagor's equity of redemption and, as a concomitant, the mortgagee's equity of foreclosure were established beyond dispute. Indeed by an Act of $1734^{\circ}$ the courts of law were given power in a suit for the recovery of the debt, or in ejectment by the mortgagee, on tender of principal and interest by the mortgagor, to order the discharge of the mortgage and to compel a reconveyance. Henceforth the mortgage was in legal theory an estate on condition, in equity a loan on security, a transaction that in its varied terms eluded precise definition. "That is the worst of our mortgage deed-," says Maitland, "owing to the action of equity, it is

${ }^{\circ}$ Coke, Littleton, *209-210; Sheppard, Touchstone, * ${ } 4 \mathrm{I}$; Goodall's Case (I597, K. B.) 5 Co. 95 .

${ }^{7}$ I Spence, Equitable Jurisdiction (1846) 60I; Kerby, Historical Sketch of the Equitable Jurisdiction ( 1890 ) I43; Toth, 132; How v. Vigures (I628) I Ch. 32.

${ }^{3}$ Roscarrick v. Barton (1672) \ Ch. Cas. 21\%. In Salt v. Marquess of Northampton [1892] A. C. I, I8, it is said by Lord Bramwell: "Whether it would not have been better to have held people to their bargains, and taught them by experience not to make unwise ones, rather than relieve them when they had done so, may be doubtful. We should have been spared the double condition of things, legal rights and equitable rights, and a system of documents which do not mean what they say. But the piety or love of fees of those who administered equity has thought otherwise. And probably to undo this work would be more costly and troublesome than to continue it."

${ }^{\circ} 7$ Geo. II, C. 20. 
one long suppressio veri and suggestio falsi. It does not in the least explain the rights of the parties; it suggests that they are other than really they are." 10

It has been stated frequently that the result of the decisions of the court of chancery was to reduce the mortgagee's interest to a mere security or charge on the land. But this has never been literally true in England where chancery has not interfered directly with the legal doctrine but has kept consistently within its own sphere of action. A mortgage made by conveyance, the common method, and not by way of charge only, confers upon the mortgagee the estate of the mortgagor. Aside from express agreement the rights of the mortgagor in possession are no more, in some respects less than those of a tenant at will. When the debt is discharged the reconveyance is by deed.11 All this chancery concedes, while at the same time it treats the equity of redemption not as a mere right but as an estate which the mortgagor may deal with in any way consistent with the rights of the mortgagee in his security. ${ }^{12}$ The fact that through the supremacy of equity over law ${ }^{13}$ the equitable viewpoint is for most purposes the more important does not militate against the legal doctrine.

Whether, then, the mortgage so developed can be designated correctly as a lien depends upon what is understood by that word, a term described by Mr. Justice Erle as "intensely undefined."14 By the common law, says Mr. Justice Grier, a lien is "a right in one man to retain that which is in his possession belonging to another, till certain demands of him, the person in possession, are satisfied. In courts of equity the term lien is used as synonymous with a charge or incumbrance upon a thing, where there is neither jus in re nor ad rem, nor possession of the thing." 15 Clearly a mortgage does not come within the description of a lien as that word is understood at common law or in equity, unless it be an informal or so called equitable mortgage. But the jurisprudence of England and America has never been careful or precise in the use of technical words, and "lien" has now come to mean, in a popular sense, any hold which one person has upon the

\footnotetext{
${ }^{20}$ Maitland, Equity (Ig09) 269.

Ix 2 I Hals. Laws Eng. I 58, I86, 3Ir ; 3 Pomeroy, Equity (3d. ed. I905) sec. II84; Copestake v. Hoper [1908, C. A.] 2 Ch. Io.

${ }^{12}$ Casborne v. Scarfe (1738, Ch.) I Atk. 603; Heath v. Pugh (I88I) L. R. 6 Q. B. Div. 345; Tarn v. Hunter (1888) L. R. 39 Ch. Div: 456.

${ }^{13}$ Judicature Act (1873) 36 \& 37 Vict c. 66 , sec. 25 , subsec. II.

${ }^{14}$ Brunsdon v. Allard (I859, Q. B.) 2 E1. \& E1. I9.

${ }^{15}$ Peck v. Jenness (1849, U. S.) 7 How. 6r2; Jones, Liens (3d ed. I914) sec. 3; Salmond, Jurisprudence (4th ed. 1913) 402. In Conrad v. Atlantic Ins. Co. (1828, U. S.) I Pet. 386, 44I, it is said by Mr. Justice Story: "It is true, that in discussions in Courts of Equity, a mortgage is sometimes called a lien for a debt. And so it certainly is, and something more; it is a transfer of the property itself, as security for the debt. ... It is therefore only in a loose and general sense that it is sometimes called a lien, and then only by way of contrast to an estate absolute, and indefeasible."
} 
property of another as security for a debt or demand. What change of view, then, has led so many courts, in spite of the form of the instrument, in the teeth of all the ancient precedents, to insist that the transaction does not give rise to a title but to a lien only?

The new theory is frequently traced to some words of Lord Mansfield, although that learned Judge cannot be charged with actual innovations in this branch of the law. The tradition that he systematically disregarded the rules of the common law for those of the civil law is largely apocryphal. ${ }^{16}$ In Keech $v$. Hall ${ }^{17}$ he distinctly laid down that the mortgagor was no more than a tenant at will subject to ejectment without notice to quit. But in several cases, in other respects decided wholly in accordance with precedent, he did use language which, taken without regard to the context lends itself to very broad construction. In Martin v. Mowlin, ${ }^{18}$ in determining that a mortgage was personal property of the mortgagee, he said: "A mortgage is a charge upon the land: and whatever would give the money, will carry the estate in the land along with it, to every purpose." This statement is no stronger than that of Lord Hardwicke twenty years earlier in a case in which Lord Mansfield, then Mr. Murray, was of counsel. The Lord Chancellor there said: "Where a mortgage is made of an estate, that is only considered as a security for money due, the land is the accident attending upon the other; and when the debt is discharged, the interest in the land follows of course." 18 In another case Lord Mansfield speaks of a mortgage as "a mere security"; ${ }^{20}$ and later, in the repeatedly quoted case of King v. St. Michaels, ${ }^{21}$ he said: "A mortgagee notwithstanding the form has but a chattel, and the mortgage is only a security. ... It is an affront to common sense to say the mortgagor is not the real owner."

In each of these cases the judgment is in accord with the orthodox views of mortgage law; in none were the quoted words necessary to the decision; their importance lies in the fact that they did not proceed from the chancery bench but were the utterances of a common law judge, a very distinguished judge whose statements carried great weight in the American courts. It is quite possible that the attitude of Lord Mansfield and the equity judges who were his contemporaries toward

\footnotetext{
${ }^{10}$ Campbell, Lives of the Chief Justices, ch 34. Cf. Lord Redesdale in Shamon v. Bradstreet (I803, Ir. Ch.) I Sch. \& Lef. 52.

${ }^{17}$ (I778, K. B.) I Doug. 2I. See also Moss v. Gallimore (I779, K. B.) I Doug. 279.

${ }^{18}$ (I760, K. B.) 2 Burr. 969; and note Judge Trowbridge's criticism in (I813)

8 Mass. 554, 557, et seq.

${ }^{2}$ Richards v. Syms (1740) Barn. Ch. 90. See also Casborne v. Scarfe, supra, note 12; and Brozen v. Gibbs (1699) Prec. Ch. 97, where Lord Somers is reported as saying that "the mortgage is looked upon as a personal contract, and the mortgagee has no interest beyond his money. ..."

${ }^{20}$ Eaton v. Jaques (I780, K. B.) 2 Doug. 455

${ }^{21}$ (1781, K. B.) 2 Doug. 630.
} 
mortgages was influenced by the civil law, although this is not apparent in their judgments. In this connection it is interesting to note that in popular works on the civil law translated into English the French hypothèque is rendered as mortgage, ${ }^{22}$ an unfortunate translation and possible source of confusion, since the mortgage of English law, even as modified in equity, bears only a limited analogy to the continental hypothec, which, following the Roman law, is essentially, a potential right of distraint and includes besides mortgages', liens for rent and taxes as well as other charges and preferred claims ${ }^{23}$ referred by English and American law to other legal categories.

But it is unsafe to attribute too much force to the chance dicta of judges, however eminent, when these utterances are themselves perhaps no more than straws showing the direction of the juridical wind, as it were; signs of social and economic tendencies silently at work. Since possession by the mortgagee had become an unprofitable burden and the practice of permitting the mortgagor to retain possession had become universal, it was inevitable that sooner or later common opinion would regard the mortgagor as owner and the mortgagee as a creditor.

Conveyancers cautiously gave effect to this conception; it became the practice to grant only a long term of years by way of mortgage, to avoid the danger that after breach of condition dower would attach as well as other encumbrances of the mortgagee, and so that, on the death of the mortgagee, the term should vest in his personal representatives who were entitled in equity to receive payment of the loan. ${ }^{24}$ Not until chancery had established the supremacy of its view did mortgages in fee become again usual. If no one had been concerned in the transaction except mortgagor and mortgagee the divergent theories of law and equity would have caused little friction incapable of adjustment by slight modifications of the terms of the conveyance. A clause providing for possession by the mortgagor until default would have blocked one source of misunderstanding. It was rather in its external aspects, its political implications that the relation of mortgagor and mortgagee called for discussion and insisted on a theory from the time its peculiar character had been detected.

Thus in the case of an estate to which an advowson was attached, while the mortgagee, as having the legal estate had the right of presentation at law; a court of equity would compel the mortgagee to present the nominee of the mortgagor. For the mortgagee was permitted no more than principal and interest, and a presentation to a church was an advantage for which the mortgagee could not give credit on an

"Ayliffe, A New Pandect of Roman Cizil Law, bk. IV, tit. I8; Domat, Civil Lawe (Strahan transl. I722) bk. III, tit. I; I Browne, Civil Lare (I840) 201.

${ }^{23}$ Brissaud, op. cit. at p. 6I5; Wigmore, The Pledge-Idea, I. (I897) Io HARv. L. REv. 32x; Digest, lib. XX.

${ }^{24} 2$ Blackstone, Commentaries, ${ }^{*}{ }_{5} 8$; Powell, Mortgages (Amer. ed. I828, from 6th Eng. ed. 1826) 703 . 
account, upon redemption, without an admission of simony. ${ }^{25}$ Under the poor laws the question arose as to whether a settlement was acquired by one in possession of land subject to a mortgage and the decision was in favor of the mortgagor because, in the words of Lord Kenyon, "neither the Courts of Law or Equity lose sight of what the parties intended." 26 Of a similar character was the question raised in Wetherell $v . \mathrm{Hall}^{27}$ where the defendant in a penal action was charged with shooting game not being qualified by the ownership of lands of the clear value of $E$ roo per annum. It appeared that the defendant was seized, in right of his wife, of lands of the yearly value of $f$ ro 3 , but they had been mortgaged for $\mathbf{f}_{400}$. Judgment was for the plaintiff, Lord Mansfield saying: "We consider the defendant's interest in this court just as it would be considered in a court of equity. It is an interest subject to the payment of the mortgage; it is a qualification of the property; and, though it is not necessary that he should have a legal estate, he must have such property in the land as shall produce a clear income of $t$ Ioo; or it might be carried so far, as that he might have nothing and yet enjoy the privilege. What then are a mortgagor and a mortgagee in chancery? One the owner, and the other as having a charge upon the land; and the charge goes with it."

Even more significant was the question of the effect of a mortgage upon the franchise. As early as $1430^{28}$ the county franchise was limited to persons possessing a freehold worth forty shillings a year above all charges (outre les reprises). Who then had the vote, mortgagor or mortgagee? When contests for the counties' representation in Parliament grew frequent, and the rights of voters more closely scrutinized, Parliament found it necessary to remove a disqualification which affected a vast number of voters by providing that no person should vote for members of Parliament "by reason of any trust estate or mortgage, unless such trustee or mortgagee be in actual possession or receipt of the rents and profits of the same estate; but that the mortgagor, or cestui que trust, in possession, shall and may vote for the same estate, notwithstanding such mortgage or trust."29 But, where land

\footnotetext{
${ }^{25}$ Jory v. Cox (1697) Prec. Ch. 7I; Amhurst v. Dawling (I700, Ch.) 2 Vern. 40r; Dymoke v. Hobart (I704) I Brown, Parl. Cas. 8I; Attorney-General v. Hesketh (I706, Ch.) 2 Vern. 549; Gally v. Selby (I72I, Ch.) I Str. 403; Mackensie v. Robinson (1747, Ch.) 3 Atk. 559; Dyer v. Lord Craven (1786, Ch.) Dick. 662.

${ }^{20}$ King v. Edington (180I, K. B.) I East, 288. Cf. King v. St. Michaels, supra note 21; King v. Chariley (I796, K. B.) 6 T. R. 755; Newark v. Pontpton (1813) 3 N. J. L. 1038; Barkhamsted v. Farmington (I818) 2 Conn. 600; NewLondon v. Sutton (182I) 2 N. H. 40I; Monnt Washington v. Clarksburgh (1837) 36 Mass. 294.

${ }^{27}$ ( 1782, K. B.) Caldecott, 230. In I779 Blackstone, J., ruled contra at the Thetford assizes, 2 Luders' Elec. Cas. 480 .

${ }^{28}$ (1429) 8 Hen. VI, c. 7. Cf. (I432) 1o Hen. VI, c. 2; (I745) I8 Geo. II, c. I8; Heywood, County Elections (I790) 62.

(I696) $7 \& 8 \mathrm{Wm}$. III, c. 25, sec. 7. Substantially re-enacted, (1832) 2 Wm. IV, ch. 45, sec. 23 ; (I843) 6 \& 7 Vict. ch. 18 , sec. 74 .
} 
was mortgaged, was the interest paid to be considered as a deduction from or charge upon the annual value? The point seems to have been first fully considered in the Bedfordshire election contest of 1785 where it was held by the committee, who seem to have been greatly influenced by Wetherell $v$. Hall, ${ }^{30}$ that interest upon a mortgage which reduced the value of the estate to less than forty shillings would invalidate the vote, notwithstanding the mortgagor's ability to pay the interest from other property. ${ }^{31}$ In a similar contest at Crickdale a few days later there was a contrary ruling, ${ }^{32}$ but subsequent decisions by the courts settled the point in accordance with the Bedfordshire committee's finding. ${ }^{33}$ It is hardly to be doubted that these cases of various sorts involving the public rights of the mortgagor, and the discussions that attended them, served to bring into clearer relief the anomalies of the mortgage contract. And while they cannot be said to have disturbed established precedents at law, their tendency was to show that in most instances the equitable view more nearly represented the . intention of the parties.

To America the colonists brought the law of mortgages very much as they found it in the mother country, making comparatively few statutory innovations, except that, in common with other conveyances, mortgages were required to be recorded. ${ }^{34}$ In some of the colonies, the absence of a court of chancery led to the introduction of statutory methods of foreclosure and redemption..$^{35}$ But, compared with the voluminous statutes on other topics, the amount of legislation was relatively small. When cases come to be reported, the title of the mortgagee, at law, is upheld as a matter of course. ${ }^{36}$ Nevertheless, the pains taken by the courts to make clear the distinction between the legal and equitable view of the mortgagor's interest indicates that the judges are well aware of a popular misconception, if it can be so called, widely prevalent. As a matter of fact, in spite of the explicit statements in the documents, few people outside of the legal profession would have regarded the transaction as involving an actual transfer of title. And, as a very considerable number of settlements were made on credit,

${ }^{30}$ Supra note 27 .

at (I785) 2 Luders' Elec. Cas. 450.

${ }^{32}$ Crickdale contest (1785) 2 Luders' Elec. Cas. 470.

${ }^{33}$ Lee v. Hutchinson (1850) 8 C. B. 16; Rolleston v. Cope (1870) L. R. 6 C. P. 292.

${ }^{34}$ See, for example, Va. Act XVİ of Jan. 6, I639, x Hening Laws, 227; Act XII of Mar. 2, I642-3, ibid. 248; Mass. Act of Oct. 30, I697, I Acts \& Resolves (1869) 298.

${ }^{35}$ Mass. Act of Dec. Io, I698, I Acts \& Resolves (1869) 356; Act of March 25, I713, ibid. 703; Pa. Act of Jan. I2, I705, 2 Stat. at L. (I896) 244.

${ }^{30}$ Moliere v. Noe (I806, Pa.) 4 Dall. 450; Erskine v. Tozensend (1807) 2 Mass. 493; Rockwell v. Bradley (I8I6) 2 Conn. I; Brozem v. Cram (I818) I N. H. I69; Parsons v. Welles (I82I) I7 Mass. 4I9; Blaney v. Bearce (I822) 2 Me. I32; Faulkner v. Brockenbrough (1826, Va.) 4 Rand. 245 ; Jamieson v. Bruce (1834, Md.) 6 G. \& J. 72. See Judge Trowbridge, Mortgages, 8 Mass. 554. 
that is, on borrowed money secured either by mortgage or vendor's lien, there grew up in each community a large group, given to rather informal dealings with land at the best, accustomed to regard with a jealous eye all institutions favorable to the creditor class. The atmosphere was distinctly unfavorable to the literal enforcement of the mortgagee's legal rights.

South Carolina was the first state to attempt to bring its mortgage law into harmony with the common misunderstanding of the public. It is quite significant that this undertaking was part of the reform legislation that followed the constitutional convention of I790. The Act of I79I, reciting in its preamble that mortgages were generally meant merely as securities for debts and no actual estate was intended to be conveyed, and providing a simpler method of foreclosure, went on to enact "that no mortgagee shall be entitled to any possessory action for the real estate mortgaged, even after the time allotted for the payment of the money secured by the mortgage is elapsed, but the mortgagor shall still be deemed owner of the land and the mortgagee as owner of the money lent or due."37 This looks like a complete departure from the common law theory, but the act went on expressly to except the case when the mortgagor was out of possession, and a supplemental act of I797 gave to a release by the mortgagor of the "equity of redemption," so called, the effect of a conveyance, ${ }^{38}$ indicating, if that were necessary, the incorrigible conservatism of the conveyancer.

While South Carolina led the way, it is to the influence of the early New York decisions that the growth of the so called lien theory of mortgages must chiefly be attributed; and it is to these decisions that one must turn in order to observe the circumstances attending the development of the new doctrine. There was at first no departure from precedent. "It cannot be denied," said Chief Justice Spencer in I809, "that the mortgagee has the title, so far as to enable him to maintain ejectment on the mortgage, not only against the mortgagor, but against such as derive title under him, subsequent to the mortgage."39 The only variation from the common law was in requiring the mortgagee before ejectment to give notice to quit. This a majority of the Supreme Court thought no hardship on the mortgagee, "while a contrary practice may be much abused, in a country where so many thousand estates are held in this way." 40 But, while orthodox in result, there will be found running through the cases from the beginning of the

"I Brevard, South Carolina Digest (I8I4) I74; Verree v. Verree (I807, S. C. L.) 2 Brev. 2II; Thayer v. Cramer (I826, S. C. Ch.) I McCord, 395.

${ }^{s}$ I Brevard, South Carolina Digest (I8I4) I77 (see introduction p. XVIII); State v. Laval (1827, S. C. L.) 4 McCord, 336; Simons v. Bryce (1878) Io S. C. 354; Navassa Gıano Co. v. Richardson (1886) 26 S. C. $40 \mathrm{r}$.

${ }^{2}$ Jackson v. DuBois, 4 Johns. 216, 221. Accord, Jackson v. Chase (1806, N. Y.) 2 Johns. 84. That the assignment of the debt will draw the land after it is decided in Green v. Hart (1806, N. Y.) I Johns. 580.

${ }^{40}$ Jackson v. Langhhead (1806, N. Y.) 2 Johns. 75. Contra, Keech v. Hall, supra note $I 7$; Rockwell $v$. Bradley, supra note 36 . 
century dicta favorable to a wide extension of the equitable view. In I804 the nature of the mortgagor's interest was fully discussed in a case where the point for decision was whether an equity of redemption was subject to sale on execution. ${ }^{41}$ The rule in England was against so proceeding since the mortgagor's interest was regarded as equitable assets; but in several states the practice of selling on execution was already established, ${ }^{42}$ and this also was the custom in New York during the colonial period, under the Statute of 5 Geo. II, c. 7, subjecting land in the colonies to sale on execution. The court adhered to the settled procedure. "I am the more confirmed in this opinion," said Spencer, J., "from the general and almost universal idea and practice which has prevailed for a series of years, as well as from the legislative declaration that a mortgagor in possession is a freeholder within the meaning of the constitution, and as such entitled to vote." In this connection it is interesting to note that the freehold qualification of voters had been preserved in New York by the constitution of $1777^{43}$ and was only abolished by the constitution of $\mathrm{I} 82 \mathrm{I}$ in deference to strong public sentiment adverse to the exclusion from the franchise of thousands of citizens who had purchased land on long term contracts by which title did not pass until full payment of the purchase money.44 As early as I7OI the mortgagor, if in possession, had been enfranchised $^{45}$ and this policy was continued in later acts. ${ }^{46}$ In the same case Kent, J., after calling attention to the language of Lord Mansfield and the tendency to adopt the "more rational ideas of chancery," went on to say that if the New York practice was an innovation it was not alarming. "A very considerable part of the lands in this state, are

${ }^{11}$ Waters v. Stewart (I804, N. Y. Senate) I Caines, Cas. 46.

In Massachusetts by the Act of July 3, I735-6, 2 Acts \& Resolves (I874) 762. In Connecticut by the court in Punderson v. Browen (I803) I Day, 93. In Pennsylvania estates both legal and equitable were held subject to sale on execution under the Act of I705, supra note 35; Rickert v. Madeira (1829) I Rawle, Pa. 325.

${ }^{43}$ Sec. 7, I N. Y. Rev. Laws (I8I3) 36.

"Fox, The Decline of Aristocracy in the Politics of New York (I919) $86 \mathrm{Col}$. Univ. Studies in Hist. 252.

${ }_{45}$ "And Whereas a Question hath arrisen whether any person or persons haveing Mortgaged his or their Lands, and being in possession thereof, and receiving the Income thereof, should not by reason of such mortgage be debarred from giving his Vote, as aforesaid, BE IT THEREFORE ENACTED, That Such mortgage shall not debar the party abovesaid from the giveing of his vote, provided he be in possession thereof, or receive the Incomes of the Same." Act of Oct. 18, I70I, I Colonial Laws of N. Y. (I894) 452, 453.

${ }^{40} \mathrm{I}$ Kent and Radcliff, N. Y. Laws (I807) 264 , sec. I5; 2 N. Y. Rev. Laws (I8r3) ch. 4I, sec. 22. This problem did not arise in colonies not requiring the freehold qualification for the franchise. See Bishop, History of Elections in the American Colonies (1893) 3 Col. Univ. Studies in Hist. 8or. In Bozers v. Oyster (I83I, Pa.) 3 P. \& W. 239, Kennedy, J., said he apprehended that a freeholder who had mortgaged would still be qualified to serve as a road viewer or juror. In State v. Ragland (1876) 75 N. C. I2, a mortgagor in possession was held a freeholder within the jury act. 
under mortgage to the loan office, and to individuals it is likely they will continue so; and if judgment creditors are under a necessity in every case of resorting to chancery for leave to sell the land of the debtor, it would create double suits and double expense, and would lead to much inconvenience and delay."

A few years later, conversely, the interest of the mortgagee before foreclosure and while the mortgagor was in possession was held not subject to sale on execution. The modern cases, said Chief Justice Kent, were tending to the same conclusions as in equity, and "whenever the nature of the case would possibly admit of it, the courts of law have inclined to look upon a mortgage, not as an estate in fee, but as a mere security for a debt." 47 In these cases the influence of Lord Hardwicke and Lord Mansfield is manifested by the frequent citation of their judgments, while that of the civil law, which Chief Justice Kent frequently quoted in other connections, does not appear. Perhaps it was unnecessary to elaborate upon points favored by obvious convenience.

The crux of the problem was the right to possession as an incident of title, a difficulty that need hardly have arisen as a matter for practical consideration, if conveyancers had been less timid and had expressly given the right of possession to the mortgagor until default, instead of blindly copying ancient forms. It was held in I8ro that a mortgage, before foreclosure or entry, was not such a legal title as a stranger could set up ${ }^{48}$ and soon afterward that a mortgagee or his assignee in possession was protected by the mortgage, ${ }^{49}$ both rulings conservative in theory. But the important case, the one that marks the point of departure from the older law, was Runyan v. Mersereau, ${ }^{50}$ decided in I8I4. The action was trespass quare clausum fregit brought by the plaintiff who was in possession as purchaser at sheriff's sale on a judgment against the mortgagor. The defendant set up a license from the mortgagee to enter and cut timber, a flimsy defense under the circumstances, for it was in evidence that the plaintiff was in possession of the bond and mortgage under an equitable assignment. Since, however, the defendant had pleaded freehold in the mortgagee and the plaintiff had replied that the freehold was in himself, the issue was, who had the freehold? The brief per curiam judgment quoted Lord Mansfield, ${ }^{51}$ stated that it was unnecessary to go into the cases and concluded: "The light in which mortgages have been considered, in order to be consistent, necessarily leads to the conclusion that the freehold must be considered in the

"Jackson v. Willard (I809, N. Y.) 4 Johns. 4I. Accord, Blanchard v. Colburn (1820) I6 Mass. 345; Rickert v. Madeira, supra note 42.

${ }^{43}$ Collizs v. Torry (I8ıo, N. Y.) 7 Johns. 278 ; Jackson v. Pratt (18r3, N. Y.) Io Johns. 38I. See also Sedgwick v. Hollenback (ISIr, N. Y.) 7 Johns. 376.

* Dein v. Wynkoop (I8xx, N. Y.) 8 Johns. I29; Jackson v. Minkler (1813, N. Y.) тo Johns. 480; Phyfe v. Riley (I836, N. Y.) I5 Wend. 248.

${ }^{20}$ (I814, N. Y.) Ix Johns. 534.

"King v. St. Michaels, supra note $2 \mathrm{r}$. 
plaintiff, and he of course is entitled to judgment." It is very probable that this question would have met with more cautious treatment had Chief Justice Kent still remained on the bench. Although liberal in his attitude toward the rights of the mortgagor, he would hardly have entered upon so marked a departure from precedent without at least giving a fully reasoned judgment. But that learned jurist had just left the Supreme Court to become Chancellor. Although inadequately considered, and in direct conflict with the common law doctrine, ${ }^{52}$ this case has had a decisive effect upon New York law. Its implications are fully accepted by Chief Justice Spencer in I8I9. "In the case of Runyan v. Mersereau we went the whole length of deciding that mortgages are to be regarded as mere securities for money, and that the freehold continues in the mortgagor." 53 Finally, in I828 it was provided by statute that a mortgagee or his assignee could not maintain an action of ejectment to recover the mortgaged premises. ${ }^{54}$

The result was that the Supreme Court of New York could say: "A mortgage is now nothing but a security for a debt, giving the mortgagee a special lien only, upon the estate mortgaged. It conveys no title to the property. The interest of the mortgagee is a mere chattel interest. The title and seisin remain in the mortgagor until foreclosure, and he is not divested of his title until all the steps required by statute have been complied with."'55 This doctrine has had wide influence and a view essentially similar now prevails in considerably more than a majority of states, although in New England and some of the older communities there is a more or less close adherence to the common law. ${ }^{58}$ But it cannot be said that the theory is consistently applied. In Phyfe v. Riley, ${ }^{57}$ it was held that a mortgagee in possession, after condition broken, could not be dispossessed in ejectment by one claiming title through the mortgagor. "It cannot be denied," said the court, "that the mortgagee has an interest in the mortgaged premises, and that interest after forfeiture is a legal interest." A fraudulent purchaser of real property may mortgage, and a bona fide mortgagee for value

${ }^{32}$ See Parsons v. Welles, supra note 36; Lackey v. Holbrook (1846) 52 Mass. 458; Chellis v. Stearns (I85I) 22 N. H. 3I2; Gilman v. Wills (1877) $66 \mathrm{Me}$. 273; 4 Kent, Commentaries, I55.

${ }^{*}$ Stanard v. Eldridge (I8rg, N. Y.) I6 Johns. 254. See also Jackson v. Bronson (I822, N. Y.) I9 Johns. 325; Dickenson v. Jackson (1826, N. Y.) 6 Cow. I47; Jackson v. Bowen (I827, N. Y.) 7 Cow. I3.

2 N. Y. Rev. Sts. 1828 , pt. 3 , ch. 5, tit. I, sec. 57 . So also in N. Y. C. C. P. 1876 , sec. 1498 , and N. Y. C. P. A. I920, sec. 991 .

${ }^{5}$ Bryan v. Butts (I857, N. Y.) 27 Barb. 503.

${ }^{35}$ See I Jones, Mortgages (7th ed. I9I5) 22 et seq. for a summary. In Louisiana the mortgage is the hypothec of the civil law. La. Civ. Code, 1870, art. 327834 II.

${ }^{5}$ Supra note 49 , at p. 255 . Accord, Bolton v. Brezuster (1860, N. Y.) 32 Barb. 389; Hubbell v. Monlson ( 1873 ) 53 N. Y. 225. So at common law Hill v. Payson (180r) 3 Mass. 559; Jackson v. Minkler, supra note 49. Cf. Barson v. Mulligan (I908) I9I N. Y. 306,84 N. E. 75. 
will be protected against the claims of the defrauded vendor..$^{58}$ In Mickles $v$. Tozensend ${ }^{59}$ land subject to a mortgage by a prior owner was conveyed by its then owner by warranty deed. When subsequently the grantor became assignee of the mortgage, he was held to take it for the benefit of his grantee. The contention that the doctrine of estoppel did not apply, inasmuch as the mortgage was not a title but a mere security for a debt, was denied. Said Denio, J.: "For some, and indeed for most purposes the mortgagor is considered seised and the mortgagee has a mere lien. Still, as between mortgagor and mortgagee, the title is considered as passing by the mortgage for many purposes. ... I am of opinion that for the purpose of applying the doctrine of estoppel, the mortgagor is considered as having an equity of redemption only, the fee being in the mortgagee and that in this case the purchase of the mortgage inured to the benefit of the plaintiff in the same way that a release of the mortgage would have done."

When it comes to defining a mortgage under the lien theory the difficulties are just as great as at common law. Professor Durfee suggests that, as the new theory is a product of the courts of law, the lien of the mortgage is a legal, as distinguished from an equitable lien. Admittedly a legal lien without possession is an anomaly; but if this distinction is not made it is difficult to find a place in the scheme for the informal or equitable mortgage. ${ }^{.0}$ It is proof of the poverty of the legal imagination that in so many instances terms definitely applied to particular purposes are forcibly appropriated to other uses. Such seems to be the fate of the word lien which had at common law a well settled meaning, as well as in equity; but now, for better or worse, has taken in the American courts a broad and somewhat vague significance, approximating roughly to the continental hypothec. Indeed the California Civil Code very properly, from the viewpoint of its draughtsman, defines a mortgage as "a contract by which specific property is hypothecated for the performance of an act, without the necessity of a change of possession."' After all the mortgage transaction that our law has slowly and empirically developed is sui generis. Here again the California Civil Code in its statutory form of mortgage is eloquent in its brevity witnessing "that the mortgagor mortgages to the mortgagee" the property described ${ }^{22}$ echoing Baron Parke's dictum that a mortgagor "can be described merely by saying he is a mortgagor." ${ }^{3}$

The law of mortgages in England and America in its progress is travelling almost the same road as the Roman law, but its path has been beset by more difficulties. Chief of these is the difference in atti-

* Simpson v. Del Hoyo (1883) 94 N. Y. 189; Swanstrom v. Day (I905, Sup. Ct) 46 Misc. 3II, 93 N. Y. Supp. 192.

(I859) I8 N. Y. 575.

${ }^{\infty}$ The Lien or Equitable Theory of the Mortgage (1912) Io Mrch. L. REv. 587.

"Calif. Civ. Code (I872) sec. 2920.

- Ibid. sec. 2948.

"Litchfield v. Ready (I850) zo L. J. Exch. 51. 
tude toward real and personal property at common law, a matter of which Roman law made little account. At common law a mortgage is a conveyance and conveyancing is in England an extremely complicated art. Mortgages form an integral part of many family settlements. To change their legal theory, to upset precedents, might be attended by consequences not easily foreseen. In the United States conveyancing has always been simpler than in the mother country, in some communities very informal indeed, affording the courts wider scope for interpretation, more room for innovation. Yet in both countries, notwithstanding the stubborn conservatism of forms and the conflict of decisions; however difficult it may be for the jurist to define accurately this complex transaction, the mortgage of to-day does not mean the same thing to the parties that it did to their ancestors when borrowing money to go to the Crusades. The creditor's security is no longer physical but legal. He would not have it otherwise, although occasionally powers or rights belonging to the dim past are revived to meet special emergencies. Indeed the very intricacy of the relation, in so far as it gives flexibility to the remedial powers of the courts, may possibly further the ends of justice. 